\title{
RECOGNITION OF FOREIGN JUDGMENTS IN BRAZIL: NOTES ON BRAZILIAN SUBSTANTIVE AND PROCEDURAL PUBLIC POLICY ${ }^{1}$
}

Carmen Tiburcio

Professor of Private International Law and International Litigation at the State University of Rio de Janeiro. LLM and SJD University of Virginia School of Law, USA. Consultant in Brazil at Barroso Fontelles, Barcellos, Mendonça \& Associados

Luís Roberto Barroso

Professor of Constitutional Law at the State University of Rio de Janeiro. LLM from Yale Law School and SJD from the State University of Rio de Janeiro. Justice of the Brazilian Federal Supreme Court

Abstract: After presenting a brief overview on the Brazilian legal system, the paper deals with the recognition of foreign decisions in Brazil, focusing on the requirement of public policy, both in the substantive and procedural aspects.

Keywords: Foreign judgments - Exequatur - Public policy.

\section{INTRODUCTION}

The purpose of this paper is to analyze the system adopted by Brazilian Law for certain issues involving recognition of foreign judicial decisions, specifically concerning substantive and procedural public policy. The issues raised involve an integrated examination of various areas of Brazilian Law.

\section{A PRELIMINARY NOTE REGARDING THE BRAZILIAN LEGAL SYSTEM}

A preliminary note about the Brazilian Legal System seems indispensable for an understanding of the issues the subject raises. For

1 The authors wish to acknowledge the assistance of Luíza Azambuja and Luisa Viana in the preparation of this article. 
classification purposes, Brazilian Law is considered part of a branch of the so-called Roman-Germanic system, in which written legislation is the main source of Law. In recent decades, however, case law has assumed a central role in the Brazilian legal system, not only due to the common use in Brazilian legislative text of relatively vague or general terms - therefore, making the Courts responsible, in the final analysis, for defining the precise meaning of the wording in each case - but also because of the special importance the legislator himself has attributed to case law ${ }^{2}$.

It so happens that in Brazil the decisions of higher courts do not automatically have a binding effect in relation to lower courts. There are mechanisms by which the Federal Supreme Court (STF), for example, can produce this kind of binding effect ${ }^{3}$, but if these mechanisms are not applied in a specific manner, each judge or Court will - strictly speaking - be free to decide, in the manner he/it deems fit, taking into account the existing body of law as a whole, with the Constitution at the top. This means that the judges and the Courts can decide differently and it is not always possible to identify which case law applies to a given subject, but merely which understandings are adopted more frequently in the Courts in relation thereto.

The preceding point is important because the subject analyzed in this study is inserted in a more general debate involving the contents of the concept of public policy. Today, the interpretation and application of fundamental rights have resulted in a series of disputes, due to the need to co-exist with other fundamental rights and with the attainment of public goals. For this very reason, even though there are constitutional and legal norms in the Brazilian legal system from which one can logically extract - directly or indirectly - some of the contents of Brazilian public policy, we must also examine, in addition to these

2 Among some of the examples of the current importance of precedents in Brazilian Law, one can cite art. 285-A of the Code of Civil Procedure (CPC), included by Law no. 11.277/2006, which authorizes the judge to issue a ruling even before the defendant has been served with process, when the issue of dispute is solely one of law and he/she has already issued rulings totally rejecting arguments in identical cases. Another example is art. 518, § 1 of the CPC, by which the judge can refuse to receive an appeal when he/she feels that the appeal violates a súmula (brief summaries of its case law) of the Superior Court of Justice or the Federal Supreme Court. Finally, but also without running out of examples, it should be noted that appeals in general can be granted or rejected in the preliminary phase by the reporting judge as a function of their conformity or non-conformity with dominant case law, especially case law of the Higher Courts. See CPC [Code of Civil Procedure], art. 557, caput and § 1-A.

3 The Federal Supreme Court can issue "súmulas" (brief summaries of its case law) that, upon being published in the official press, will have a binding effect on the other bodies of the Judicial Branch and the direct and indirect public administration in the federal, state and municipal spheres. These are the so-called binding súmulas, expressly established in the Federal Constitution (art. 103-A). 
laws, the tendencies of case law, which is not always consistent with what these laws seem to indicate.

\section{BRAZILIAN LEGISLATION AND THE RULES APPLICABLE TO RECOGNITION OF FOREIGN JUDGMENTS}

The recognition and execution of foreign judgments in Brazil is basically regulated by the Introductory Law to the Brazilian Civil Code (LICC - Decree-Law No. 4.657/42, now LINDB- Introductory Law to the Brazilian Legal System) and, at the moment, by the Superior Tribunal of Justice (STJ) Resolution No. 09 dated May 04, 2005, which governs the procedure for recognition of foreign judgments (formerly under the competence of the Federal Supreme Court and currently under the competence of the STJ by means of Constitutional Amendment (EC) No. 45/2004).

Article 15 of the Introductory Law to the Brazilian Legal System lists the requirements for the foreign decision to be recognized in Brazil:

"Article 15. A sentence rendered abroad shall be
executed in Brazil provided it has the following
requisites: a) having been rendered by a competent
court; b) the parties having been cited and having
taken part in the action or having allowed judgment
to go by default; c) being a final decision and having
fulfilled the necessary formalities for execution in
the place where it was rendered; d) having been
translated by an authorized interpreter; e) having
been homologated by the Federal Supreme Court."

In addition to the formal requirements quoted above, it is essential that the foreign decision does not violate national sovereignty, good morals and public policy. This is set forth in Article 17 of the LINDB as follows:

"Article 17. Laws, acts, and judgments of other countries, as well as any declarations of volition, shall not be enforceable in Brazil when they offend national sovereignty, public order and good morals."

4 Constitutional Amendment No. 45/2004 transferred from the STF to the STJ the competence to recognize foreign decisions. 
Along the same lines, Article 6 of Resolution No. 09/2005 of the STJ determines: "neither a foreign judgment nor a rogatory letter will receive exequatur if sovereignty or public policy is violated".

\section{SOME NOTES ON THE CONCEPT OF PUBLIC POLICY}

The term public policy consists of an open concept, not defined in any legal provision ${ }^{5}$. Notwithstanding, it is possible to identify it as being the set of values and fundamental political choices prevalent in a particular society at a particular time in history, as a rule, specified in the Constitution and legislation in force, especially in countries belonging to the civil law system, as Brazil.

Within the concept of public policy, legal commentators point to the existence of a number of levels, such as first, second and third grade of public policy ${ }^{6}$. Put simply, first grade public policy consists of public policy within the domestic arena, that is, the rules and principles of the Brazilian legal system deemed mandatory and that cannot be derogated as a result of the will of the parties. It should be said that, in the national sphere, public policy coincides with the concept of mandatory rules. The second grade of public policy, within the private international law arena, is the one that prevents the application of foreign laws, acts and decisions that are contrary to the public policy of the forum. Third degree public policy consists of a set of principles applicable primarily to international relations, comprising the interests of the world community as a whole and are placed above the national legal systems.

As it is quite obvious, the sphere of recognition of foreign decisions deals primarily with second grade public policy, which

5 See DOLINGER, Jacob, Ordem pública mundial; ordem pública verdadeiramente internacional no direito internacional privado, Revista de Informação Legislativa do Senado Federal v, 90, 1986, p. 211. See, also, on the principle of public policy in private international law, DOLINGER, Jacob. Direito internacional privado - Parte geral. Rio de Janeiro: Renovar, 2008 , p. 3.

6 Check the concepts in DOLINGER, Jacob, Ordem pública mundial; ordem pública verdadeiramente internacional no direito internacional privado, Revista de Informação Legislativa do Senado Federal, v. 90, 1986, p. 211: “Thus, identified as first grade public policy, is the one in the domestic sphere that sets forth, for instance, the invalidity of contractual clauses that hurt basic principles of the legal system; the second grade would be the one preventing the applicability of foreign laws, acts and decisions contrary to domestic public policy and that, consequently, produce effects in the international sphere. Third degree public policy is the one that establishes the universal principles, in the various international law fields, as well as in international relations, serving the highest interests of the world community, the common hopes of mankind. It is related to a set of values placed above the national legal systems that, eventually, can even be in collision with the circumstantial interests of the States individually considered." 
involves the possibility of preventing the application of a foreign law, act or decision in the domestic arena. There are four relevant notes that should be made on this topic.

Private international law, in accordance with local connecting rules, admits the application of foreign laws that are different to those of the forum. Due to international comity, to the respect between countries and to the tolerance towards what is different - essential in this field of law - it is admissible to apply foreign laws that are contrary to mandatory local rules.

Hence, and that is the first important observation to be made, not all mandatory rules (first grade public policy) are deemed to integrate the "second grade public policy", able to obstruct the applicability of the competent foreign law" ${ }^{7}$. In truth, second grade public policy corresponds to a selection of the most relevant elements of the first grade public policy, as will be discussed further on.

Secondly, it is important to point out that second grade public policy will be employed in two different contexts, although closely related: in the case of direct applicability of the foreign law or in the case of the indirect application of the foreign legislation, such as is the case of recognition of foreign judgments. The distinction is relevant, as the contents of public policy will be more restricted in the second case.

That is to say that whenever the local judge has to take foreign legislation into account to regulate the situation under analysis, this will be a case of direct applicability. Indeed, in the event of relationships with overseas ramifications, the applicable law is determined in accordance with the so-called connecting rules - an instrument of private international law to determine the applicable legislation in each case - which may consider the foreign legislation to be applicable. In this context, second grade public policy works as a protection device to prevent the application of foreign legislation contrary to the legal system of the forum. Thus, in the event the connecting rules determine the applicability of the foreign law, the judge must analyze, on a caseby-case basis, the content of the foreign legislation in order to verify whether there is any aspect contrary to Brazilian public policy, national sovereignty or good morals. In the event he or she concludes that there

7 This is the lesson that can be extracted from the decision of the STF in a case involving the adoption of a Brazilian by an alien and in which the alien, of German nationality, was only 12 years older than the adoptee, which violated Article 369 of the 1916 Civil Code, according to which the minimum age difference should be 16 years. STF, DJU 7 Mar 1986, SE 3638/ Alemanha, Rel. Min. Carlos Madeira: "The ruling of Article 369 of the Brazilian Civil Code is not of Public Policy, but of public interest, thus the lex fori is not effective in a case of an adoption regulated by a foreign law [German law, in this case]". And later on: "Certainly, in our country, the provision of Article 369 of the Civil Code is of public interest, which is not enough to consider it a provision of public policy". 
is such a violation, the foreign legislation is put aside and the forum law is applied (lex fori).

In the sphere of indirect applicability of foreign law - being that the case of the recognition of foreign judgments - public policy normally prevents recognition of foreign judgments contrary to national fundamental principles, as per Article 17 of LINDB. Nevertheless, this protection device will have a more restricted scope in this case, due to a fundamental principle of private international law, according to which vested rights validly acquired abroad should be respected as a rule.

That is: public policy has a decreasing scope of application: broader in the domestic arena, and more restricted in the applicability of foreign legislation; in the case of recognition of foreign judgments, that is indirect applicability of foreign law, there is an even greater restriction. In this last hypothesis, the prevailing rule is to respect the situations validly constituted abroad. Public policy will impose the nonrecognition of the foreign decision only under extreme circumstances, when fundamental principles of the forum where the decision will be executed are seriously disrespected.

The third observation to be made regarding second grade public policy, especially the one able to prevent recognition of foreign decisions, involves the content of this concept. As already mentioned, it is not sufficient that the foreign law be different from the local rules, as this is the core of private international law: allow for the applicability of the foreign law to which the juridical relationship is more closely connected in comparison to that of the forum. On the other hand, it is not possible to recognize each and every foreign decision solely based on the argument that situations validly constituted abroad should be respected. It is fundamental to set forth a minimum set of guarantees of the domestic legal system that under no circumstances may be violated.

Traditionally, the role of defining this set of guarantees has always been granted to private international law commentators, and in particular to the decisions rendered by the STF, which over the years has denied recognition to several foreign decisions grounded on this argument ${ }^{8}$. Although there is no final list of the elements of the public

8 See, only as examples, some of the elements already considered by the STF as violating public policy and which led to the non-recognition of the foreign decision: (i) lack of motivation of the foreign decision (RTJ 95:34, SE 2521/Japan, Rel. Min. Antonio Neder; and DJU 24 Oct 1986, SE 3262/USA, Rel. Min. Djaci Falcão: DJU 16 Aug 2010, SEC 684/US, Rel. Min. Castro Meira); (ii) decisions of divorce between aliens and Brazilians, before divorce was admitted in Brazil (DJU 27 July 1950, SE 1188, Rel. Min. Ribeiro da Costa; DJU 12 April 1952, SE 1285, Rel. Min. Edgard Costa; and DJU 27 Nov 1958, SE 1630, Rel. Min. Barros Barreto); and (iii) decisions rendered in face of defendants domiciled in Brazil and served through other means than by rogatory letter (DJU 12 Nov 2004, SE 7696/HL, Rel. Min. Marco Aurélio; DJU 13 Dec 1996, SE 4605 AgR/EU, Rel. Min. Carlos Velloso; DJU 21 Mar 1986, SE 3534, Rel. Min. 
policy concept able to prevent recognition of foreign judgments, there is a certain consensus that such concept consists of fundamental legal, economic, moral and social principles of the forum where the decision will be executed ${ }^{9}$.

From a juridical viewpoint, this understanding was corroborated by Brazilian law, when the 1988 Constitution adopted the category "fundamental principles" which allow for the filing of the action called Argüição de Descumprimento de Preceito Fundamental (ADPF) - Argument of Non-compliance with a Fundamental Principle ${ }^{10}$. Indeed, the constitutional legislator has recognized that among all the constitutional provisions, there is a specific group of rights deemed of fundamental importance to the legal system as a whole and that, if violated, should give rise to a specific remedy.

In spite of the fluidity typical of the indeterminate concepts, there is a set of rules that undeniably should be comprised within the scope of these fundamental principles. In this category are the foundations and objectives of the Republic, as well as the structural political decisions, all comprised within the general concept of fundamental principles, object of Title I of the Constitution (Articles 1 to 4). Along the same lines, there is a consensus that this concept also comprises fundamental rights, namely the individual, collective, political and social rights. Moreover, one should also add to the minimum content of these fundamental principles the rules comprised in the concept of the constitutional provisions that are not subject to restrictive amendments (cláusulas pétreas) (Article $60, \S 4$ ) or deriving directly from them and, lastly, the constitutional principles called sensitive principles (Article 34, VII), which are those which, given their importance, may give rise to federal intervention ${ }^{11}$.

\section{The fourth and last note to be made on the subject involves}

Sydney Sanches: ; DJU 15 Mar 2013, SEC 5543/EX, Rel. Min. Ari Pargendler; DJU 19 SEP 2012, SEC 1970/EX, Min. Rel. Humberto Martins);(iv) cumulation of monetary restatement and of exchange rates. (DJU 02 Feb 2014 , SEC 2410/EX, Rel. Min. Napoleão Nunes Maia Filho); (v) matter already decided by the Brazilian courts (DJU 12 Jun 2011, SEC 1271/EX, Rel. Min. Castro Meira; DJU 07 Jun 2011, SEC 5302/EX, Rel. Min. Nancy Andrighi); (vi) bankrupcy(DJU 15 SEP 2010, SEC 1734/PT, Rel. Min. Felix Fischer).

9 DOLINGER, Jacob. Direito internacional privado - Parte geral. Rio de Janeiro: Renovar, 2008 , p. 394.

10 The ADPF was regulated in the original text of the Constitution - sole paragraph of Article 102, after converted into $\S 1$ by Constitutional Amendment No. 3, of 13.03.93 -, with the following text: "The allegation of disrespect a fundamental principle deriving from this Constitution will be examined by the STF, in accordance with the law". The ADPF was only regulated eleven years afterwards, with the enactment of Law No. 9.882, of December 3, 1999, which sets forth about the proceedings and judgment.

11 BARROSO, Luís Roberto. O controle de constitucionalidade no direito brasileiro: exposição sistemática da doutrina e análise crítica da jurisprudência. São Paulo: Saraiva, 2012, p. 279. 
an almost intuitive classification regarding the content of the norms within the concept of public policy. In addition to the classification according to its grade, public policy can also be divided into matters of (i) substantive law and (ii) procedural law, when they are deemed of fundamental importance in the forum of execution of the decision.

The analysis of substantive public policy in the requests for recognition of foreign judgments is a tradition in Brazilian law. There are several decisions which have been denied exequatur because it would lead to a situation deemed contrary to the fundamental principles of the country. Examples of these are the foreign decisions of divorce before 1977, which were denied exequatur because their merits (divorce) would violate Brazilian public policy ${ }^{12}$, and foreign decisions of divorce in which the husband repudiates the wife ${ }^{13}$. In the case of a foreign decision of annulment of a marriage, the STF has expressly resorted to the public policy device to prevent recognition. In the case, the spouses had obtained the annulment of the marriage abroad based on the incompetence of the civil registrar officer who celebrated the marriage, and the STF has concluded that Brazilian public policy would be violated if such fragile grounds were admitted to annul the marriage, as Brazilian law seldom allows for the annulment of marriages even those based on far more serious grounds ${ }^{14}$.

Procedural public policy, in its turn, comprises a set of guarantees of a procedural nature, inherent to the due process of law, deemed fundamental principles as per the 1988 Constitution. It should be pointed out that some objective elements of the due process of law clause - such as the competence of the judge who renders the decision and the need for the defendants to be properly served - are formal requirements deemed essential for the exequatur, as per Article 15 of LINDB, above. Nevertheless, such elements are not enough to determine whether there has been a minimum compliance to the

12 STF, DJU 27 Jul 1950, SE 1188, Rel. Min. Ribeiro da Costa; STF, DJU 12 Apr 1952, SE 1285, Rel. Min. Edgard Costa; STF, DJU 27 Nov 1958, SE 1630, Rel. Min. Barros Barreto. Along the same lines, it is important to mention a Dutch divorce decision which was not recognized because it was rendered based on adultery committed when the couple was already separated in Brazil - and, consequently, the obligation of faithfulness had already ceased. (STF, DJU 6 Aug 1976, SE 2174/The Netherlands, Rel. Min. Djaci Falcão).

13 STF, DJU 26 May 1977, SE 2.373, Rel. Min. Thompson Flores.

14 STF, DJU 2 May 1997, SE 4297/Chile, Rel. Min. Carlos Velloso: "Well, if the Brazilian public policy does not allow a marriage to be annulled because of incompetence of the officer of the Civil Registry who celebrated the marriage, but on the contrary allows the matrimony to be celebrated in front of any officer of the Civil Registry, private international law in Brazil cannot admit such a fragile ground for the annulment of marriages". Justice Carlos Velloso quoted two other precedents of a similar nature, namely: STF, DJU 27 Oct 1989, SE 3886/ Chile, Rel. Min. Francisco Rezek; and STF, DJU 18 Mar 1991, SE 4312/Chile, Rel. Min. Néri da Silveira. 
guarantee of due process of law. Even when the judge is competent and the defendant was regularly served, if the parties are not guaranteed the right of defense or, for example, are subjected to endless appeals which only one party is entitled to file, clearly the due process of law clause has been disrespected in even its most basic level.

Taking into account only the foregoing, it is already possible to affirm that the following are fundamental principles for the Brazilian legal system, and as such are comprised within the concept of public policy able to prevent recognition of foreign decisions: (i) the preservation of legal certainty and as its corollary, the protection of the perfect juridical act; (ii) the obligation that the public administration, in a State based on the law, acts with a minimum good faith and morality towards the individuals; (iii) the protection of the right to property, preventing expropriation without indemnification; and (iv) the guarantee that everyone is assured essential elements of due process, such as equality among the parties, including the opportunity to be heard and to present one's claims and defenses.

As a consequence, a foreign decision which violates a perfect juridical act, consecrates uncertainty and legal insecurity, corroborates openly-disloyal conduct of the public administration towards private individuals, disrespects, without any payment of compensation, the right to property, and/or ignores basic guarantees of the procedural due process, cannot receive recognition of the Superior Tribunal of Justice. Such a decision cannot be effective in Brazil, as its content would clearly violate Brazilian public policy. The issue will be discussed further on the next topics.

\section{SUBSTANTIVE PUBLIC POLICY}

\section{V.1. Legal certainty and protection of perfect juridical acts}

Common knowledge, over a long period of time, consecrates security - and within this concept, legal certainty - as one of the foundations of the State and of the law, side-by-side with justice (fairness) and, more recently, with social well-being ${ }^{15}$. Democratic theories about the origins and justification of the State, of a contractual nature, are based on a commutative contract: one receives in security

15 ÁVILA, Humberto, Sistema constitucional tributário. São Paulo: Saraiva, 2006, p. 303 emphasizes that the principle of legal certainty, besides deriving directly from the State based on the law, also originates from other more specific constitutional rules, such as the protection to vested rights, to perfect juridical act and res judicata, as well as the rules of legality, nonretroactivity and anteriority. 
that which is granted in freedom. Security, consecrated in Article 2 of the Declaration of the Rights of the Man and Citizen, of 1789, as a natural and inalienable right, is also comprised in the 1988 Brazilian Constitution, side-by-side with other rights, such as the right to life, freedom, equality before the law, and property, in the express terms of the heading of Article 5.

The duty of the State to assure predictability and stability of juridical relationships is comprehended within the right to legal certainty. Several rules existent in the Brazilian legal system are related to this goal, such as the ones dealing with the statute of limitations, non-retroactivity of laws and of the latest interpretation of legislation already in force, etc.

As a direct corollary of the right to legal certainty, the Brazilian Constitution protects the perfect juridical act, res judicata and vested rights against the incidence of new laws, as per the express terms of Article 5, XXXVI. Furthermore, as a result of Article 60, $\S 4$, even constitutional amendments may not disrespect the perfect judicial act. Along the same lines, and for even more reason, as they are all subject to the law, the Executive and the Judiciary may not disregard the perfect juridical act. These constitutional provisions are largely observed by court decisions, and the STF has already decided on several occasions that the protection of a perfect juridical act cannot be put aside either by the so-called "public policy laws" or by "reasons of State". The decisions quoted below reveal the importance of this guarantee to the Brazilian legal system:

"Article 5, XXXVI, of the Federal Constitution applies to each and every infra-constitutional legislation, no distinction being made whether it be a public or a private law or if it be a mandatory or facultative provision. Indeed, as in Brazil, the principle of respect to vested rights, perfect juridical acts and res judicata is of a constitutional nature, no exception being made to any type of ordinary legislation, the argument presented by many - influenced by the law of the countries in which the provision is set forth in the ordinary legislation -makes no sense that public policy legislation is immediately applied, affecting the future effects of the perfect juridical act or of the res judicata, and that is why, if the effects are altered, it is obvious that changes in the case are being introduced, which is prohibited by 
the Constitution." "I6

"PUBLIC POLICY LAWS - REASONS OF STATE - GROUNDS WHICH DO NOT JUSTIFY DISRESPECT BY THE STATE OF THE CONSTITUTION - PREVALENCE OF THE PROVISION SET FORTH IN ARTICLE 5, XXXVI, OF THE CONSTITUTION. - The possibility of state intervention in the economic sphere does not release the public administration of the duty to respect the rules that derive from the Brazilian constitutional system. Reasons of State - grounds which often consist of political grounds aimed to justify, in practice, ex parte principis, the unacceptable adoption of measures of a normative character - cannot be invoked to enable disrespect of the Constitution itself. Public policy provisions - which are also subject to the rule of Article 5, XXXVI, of the Political Charter (RTJ 143/724) cannot obstruct the full effect of the constitutional order, hindering its integrity and disrespecting its authority." 17

Still in this context, and in addition to the specific rules that protect the perfect juridical act, both the Federal Supreme Court and the Superior Tribunal of Justice argue that the possibility of unlimited revision of the juridical acts, even if there is not a specific statute of limitations, is incompatible with the constitutional principle of legal certainty. This is even more true when the validity of the act has not been questioned for a long period of time and factual situations have already been consolidated taking into account the juridical act in question. It is worth quoting the following decisions in this respect:

"Writ of mandamus. 2. Decisions of the Federal Accounts Tribunal (TCU). Presentation of accounts of the Empresa Brasileira de Infraestrutura

16 STF, RTJ 143:724 et seqq, ADIn 493/DF, Rel. Min. Moreira Alves. Along the same lines, among others: STF, DJU 6 Dec 2002, RE 263161/BA, Rel. Min. Ellen Gracie; STF, DJU 13 Sept 2002, RE 248694/SP, Rel. Min. Moreira Alves; STF, DJU 6 Jun 1997, RE 205193/RS, Rel. Min. Celso de Mello; STF, RTJ 89:634, RE 88790/RS, Rel. Min. Moreira Alves; STF, RTJ 90:296, RE 89430/BA, Rel. Min. Rodrigues Alckmin; STF, RTJ 107:394, RE 99601/SP, Rel. Min. Rafael Mayer; STF, RTJ 112:759, AI 99655-AgR/SP, Rel. Min. Moreira Alves; and STF, RTJ 164:1144, RE 205622/RS, Rel. Min. Ilmar Galvão.

17 STF, DJU 6 Jun 1997, RE 205193/RS, Rel. Min. Celso de Mello. 
Aeroportuária - INFRAERO. Public service. Regularization of admissions. 3. Hirings carried out in accordance with a selection process without a public contest, validated by an administrative proceeding and by a previous decision of the TCU. 4. More than ten years have passed since the provisional measure in the writ of mandamus. 5 . Obligation of compliance with the principle of legal certainty as a sub-principle of the State based on the law. Need for stability of the situations created administratively. (...) 8. Circumstances that, in addition to the long period of time passed, put aside the alleged nullity of the contracts of the plaintiffs. 9. Writ of Mandamus granted." 18

"Writ of Mandamus. 2. Revoking of a special pension by the Federal Accounts Tribunal. (...) Pension granted twenty years ago. (...) 7. Applicability of the principle of legal certainty, as a sub-principle of the State based on the law. The possibility of revocation of administrative acts cannot last forever. Power to annul, subject to a reasonable time. Need for stability of the situations created administratively. (...) 9. Principle of trust as an element of legal certainty." 19

"In evaluating the validity of administrative acts, it is essential to balance the rigidity of the principle of legality, for it to be placed in harmony with the principles of stability in the juridical relations, of good faith and other values essential to the perpetuation of the concept of the State based on the law "20.

"This Court has adopted the understanding that in

18 STF, DJU 5 Nov 2004, MS 22357/DF, Rel. Min. Gilmar Mendes.

19 STF, DJU 17 Sept 2004, MS 24268/MG, Rel. Min. Ellen Gracie. Similarly, see also STF, DJU 1st Aug 2003, QO in Pet. 2900/RS, Rel. Min. Gilmar Mendes; STJ, DJU 21 Aug 2012, Ag no Resp 1205434/RS, Rel. Min. Napoleão Nunes Maia Filho; STJ, DJU, 1st Dec 2009, RMS 20572/DF, Rel. Min. Laurita Vaz and STJ, DJU 16 Jun 2009, Resp 1047524/SC, Rel. Min. Jorge Mussi

20 STJ, DJU 16 Sept 1991, REsp 6518/RJ, Rel. Min. Gomes de Barros; STJ, DJU 11st Dec 2013, MS 18554/DF, Rel. Min. Napoleão Nunes Maia Filho and STJ, DJU 14 Mar 2011, RMS 25219/PR, Rel. Min. Maria Thereza de Assis Moura. 
the event there is a factual situation that has been consolidated by the passing of time, the student benefiting from the transfer shall not suffer the later revocation of the decisions that have granted him or her said right. A case in which the interested party is about to graduate." 21

\section{V.2. Good faith and basic morality in the relationships between the State and the private agent}

The obligation of the Public Administration to act in good faith derives logically from one of the fundamental principles of the Brazilian State: the decision to organize a democratic State based on the law ${ }^{22}$. This is because the relationship that exists between the Public Administration and the private agent does not oppose two private parties, each defending their own interests, although also among private parties there is the obligation of reciprocal good faith ${ }^{23}$. As a matter of law, the Administration derives its authority from the people it governs, acting in the name and on behalf of the whole population and not in its own right, and therefore it is not conceivable that it acts in a disloyal manner towards its own people. Besides being a direct corollary of any democratic State based on the law, good faith is directly associated to the duty of morality of the Administration (CF, Art. 37, caput ${ }^{24}$ ), and is also fully regulated by the Brazilian infra-constitutional order ${ }^{25}$.

21 STJ, DJU 7 Mar 2005, REsp 653383/RS, Rel. Min. Teori Albino Zavascki.

22 CF: "Article 1. The Federative Republic of Brazil, formed by the indissoluble union of the states and municipalities and the Federal District, is a legal democratic state and is founded on:...". See on this point Celso Antônio Bandeira de Mello, Direito administrativo na Constituição de 1988, 1991.

23 See, among others, NEGREIROS, Teresa. Fundamentos para uma interpretação constitucional do princípio da boa-fé. Rio de Janeiro: Renovar, 1998; and MARTINS-COSTA, Judith. A boa-fé no direito privado, São Paulo: RT, 2000.

24 FIGUEIREDO, Marcelo. O controle da moralidade na Constituição. São Paulo: Malheiros, 1999, p. 104. See, also DELGADO, José Augusto, O princípio da moralidade administrativa e a Constituição Federal de 1988, Revista dos Tribunais v. 680, 1992, p. 34. "The observance of the principle of administrative morality imposes on the public agent the duty to imbue all of its acts with the characteristics of good faith, veracity, dignity, sincerity, respect, absence of falseness, fraud and willful misconduct"..

25 Law No. 9.784/99 (Regulates the administrative proceedings in the sphere of the federal public administration): "Article 2. Public Administration will obey, among others, the principles of legality, finality, motivation, reasonableness, proportionality, morality, right to present one's defense, confrontation, legal certainty, public interest and efficiency. Sole paragraph. In administrative proceedings, shall be observed, among others, the criteria of: (...) IV - conduct in accordance with ethical values of propriety, decorum and good faith." 
From another perspective, good faith is considered by legal commentators as a general principle of $1 \mathrm{law}^{26}$, applicable to public and private entities, which for this reason alone would characterize it as part of the Brazilian substantive public policy. Hence, either because it derives from one of the fundamental principles of the Brazilian State or because it is part of the general principles of law, foreign decisions that violate a minimum level of good faith in the relationships between the State and private agents should not be recognized in Brazil.

This premise having been established, it is important to analyze the content of the principle of good faith. In addition to the widespread general definitions mentioned by legal commentators - absence of malice and absence of desire to defraud or to seek an unconscionable - it is also possible to affirm that the principle of good faith demands from the public authorities an specific duty: it imposes respect to be given to the legitimate expectations of the private agents, created as a result of acts performed by the Administration itself.

That is to say, the duty of good faith imposes on the Administration the obligation to act coherently and logically, respecting the legitimate expectations of the citizens, created as a result of their having observed the behavior of the Administration itself. By endeavoring to adjust to this pattern of behavior, the private agents practice acts that produce effects within the sphere of their rights and obligations, in the belief that the Administration will behave, in the present and in the future, in a manner that is coherent with its practices in the past. The protection of the trust or legitimate expectations is a principle aimed, primarily, for the Public Administration ${ }^{27}$ and the Judiciary ${ }^{28}$. It is incumbent upon

26 MELLO, Celso Antonio Bandeira de. Contrato administrativo: Fundamentos da preservação do equilíbrio econômico financeiro, Revista de Direito Administrativo v. 211, 1992, p.22: "Well, the duty to act in accordance with the principle of loyalty and good faith is not only found in the relationships between private agents. Above all, it corresponds to one of the most important general principles of law, applicable also to the relations constituted in the public law arena."; and BORGES, Alice Gonzalez, Valores a serem considerados no controle jurisdicional da Administração Pública: segurança jurídica - boa-fé - conceitos indeterminados - interesse público, Interesse Público v. 15, 2002, p. 89. See also, among foreign legal commentators, PEREZ, Jesus Gonzalez , El principio general de la buena fé en el derecho administrativo. Madrid: Civitas S/A,1989.

27 On this, see DI PIETRO, Maria Sylvia Zanella, Direito administrativo. São Paulo: Atlas 2012, p. 85.

28 STJ, DJU 27 Mar 2000, REsp 227940/AL, Rel. Min. Jorge Scartezzini: “The Judiciary owes to the citizen, in identical situations, a firm, certain and homogeneous answer. In this manner, the values protected in the political-constitutional and juridical material order, with the correct jurisdictional conduct, are attained, as means of certainty and security for the society. The technical procedural strictness is set aside, according to which the applicability of substantive law is denied, to reach the adequate goal of the judicial task, that is security of a uniform result to identical situations”. See, also, STJ, DJU 2 Apr 2001, AGA 304282/SP, Rel. Min. Francisco 
these powers to apply the law to the situations on a case-by-case basis and, in this task, they should behave in a consistent and predictable manner, as it is their duty to preserve the existing legal order and to ensure equality before the law.

Clearly, not every single expectation of the private agent deserves juridical protection. For that reason, Brazilian and foreign legal commentators have established some parameters to confer greater legal substance and density to the notion of legitimate expectation that deserves protection. Two out of these merit special mention. Firstly, it will be deemed legally legitimate, and will deserve protection, an expectation that derives from objective behavior of the Public Administration, that is, which is not just wishful thinking, unconnected to real and objective elements of State practice ${ }^{29}$. Secondly, an expectation will be deemed worthy of protection if the state behavior that originated it lasted for a reasonable length of time, so that it can be deemed consistent and able to transmit the idea of stability, leading the private agent to practice acts based on this conduct.

There are mechanisms that the State can legitimately resort to in order to enforce its political decisions, but even these mechanisms are subject to juridical limitations that cannot be put aside. A pertinent example of this point is expropriation - admissible in many countries. The State is allowed to expropriate the property of private agents, but is obliged to indemnify the owners. This is because good faith requires coherence from the State - as a permanent entity - and not just from each government, with regard to its acts or past acts with which it happens to agree. This minimum level of good faith in the relationships between the Public Administration and private agents constitutes an essential element of Brazilian public policy.

In summary: good faith in the relationships between the State and private agents is part of Brazilian substantive public policy as a fundamental principle. To disrespect expectations of the public, created as a result of a constant and consistent conduct of the Administration itself, represents manifest disloyalty and fraud of the confidence placed by the public in the Administration as a whole. A decision that encompasses this type of violation to Brazilian public policy should not produce effects in Brazil.

Falcão.

29 See the decision of the European Court of Justice, in which a similar criterion was adopted. Case 375/03, decision of March 10, 2005: "Any trader on the part of whom an institution has inspired reasonable expectations may rely on the principle of the protection of legitimate expectations. (...) However, if those traders can foresee the adoption of the Community measure which affects their interests, the benefit of the principle of the protection of legitimate expectations cannot be invoked (Case C-22/94 Irish Farmers Association and Others [1997] ECR I-1809, paragraph 25, and Di Lenardo and Dilexport, cited above, paragraph 70)". 


\section{V.3. Property rights and equality before the law: impossibility of expropriation without indemnification and prohibition of unjust enrichment}

Two other elements of Brazilian substantive public policy, relevant to the case under analysis, are the right to property and equality before the law. The Brazilian Constitution guarantees the right to property not only as an individual right (Article 5, XXII), but also as a principle of the economic order (Article 170, II), guaranteed with regard the infra-constitutional legislator and also with regard to the constitutional legislator (Article 60, § 4, IV).

As it is intuitive, the right to property is not absolute ${ }^{30}$. The Constitution itself regulates the social function of property (Articles 5, XXIII, 182 et seqq. and 186 et seqq.) and establishes the various forms through which this right may be limited. This does not mean that the State can freely intervene in private property. As is the case with all other individual rights, any restriction to its enjoyment shall only be valid if the constitutional parameters have been properly observed.

There is no need to mention here all the constitutionally admissible forms of restrictions to the right to property ${ }^{31}$, it will suffice to refer to just one of them, directly pertinent to the case under analysis: expropriation. Brazilian law admits that the Public Administration may take from the private agent the enjoyment of a specific asset when this is necessary or convenient in order to fulfill a particular public interest. In any case, however, the private agent will have to be indemnified for the reduction of his or her assets (Articles 5, XXIV and XXV, 182, $\S 4$, III and 184). As a matter of interest, it should be mentioned that within the concept of property, all disposable rights are included, not only the ownership of corporeal, tangible goods ${ }^{32}$. Intellectual property

30 See, on the matter, TEPEDINO, Gustavo. A nova propriedade (O seu conteúdo mínimo, entre o Código Civil, a legislação ordinária e a Constituição), Revista Forense v. 306, 1989, p.73.

31 The 1988 Charter, when dealing with the topic, not only regulated the social function of the property but also authorized, exhaustively, four manners of state intervention in private property, namely: a) institution and charging of taxes, respecting the constitutional limitations of the power to tax (Article 148 et seq, especially Article 150), among which there is the prohibition of the use of taxation as means of confiscation; b) through due process of law, according to which the parties are granted the right to present their defense and to confrontation (Article 5, LIV and LV); c) the taking of property (Article 5, XLVI, b) and the expropriation, without indemnification, of the assets involved in the growing of psychotropic plants and traffic of drugs (Article 243), as a means of punishment; and d) the expropriation, guaranteeing always prior and fair indemnification, and the request for temporary occupation, also guaranteeing the indemnification, if there is any damage (Articles 5, XXIV, 182, § 4, III, 184 and 5, XXV).

32 ASCENSÃO, José de Oliveira, A violação da garantia constitucional da propriedade privada 
(related to trademarks and patents) is, undoubtedly, comprised within this concept.

So, Brazilian law does not admit expropriation of property without indemnification ${ }^{33}$. In this situation, the conduct of the Public Administration would be equivalent to plunder by private agents, which when carried out by the State would be called confiscation. It is interesting to observe that, nowadays, it is more common to discuss so-called indirect expropriation - cases in which the State, without employing the formal means to expropriate, takes in practice the assets of the private agent, in which case indemnification is also required ${ }^{34}$ - rather than confiscation, given that, for a long time now, the idea of allowed confiscation by the State has simply ceased to exist ${ }^{35}$.

In a very known case, Professor Haroldo Valladão has issued a declaration stating that a certain foreign decision should notbe recognized in Brazil. In that particular case, Czechoslovakia had nationalized a private company without the payment of any indemnification to its shareholders. Basing his opinion on several legal commentators, the Professor affirmed that "nationalization without indemnification, in the event of incorporation to the State without payment to the shareholders - are laws and acts openly contrary to our public policy, which will be ineffective in Brazil"36. The Federal Tribunal of Appeals upheld the

por disposição retroativa, Revista da Consultoria Geral do Estado do Rio Grande do Sul v.18, p.73.

33 TORRES, Ricardo Lobo Torres, Os direitos humanos e a tributação - Imunidades e isonomia. Rio de Janeiro: Renovar, 1995, p. 109 et ss.

34 Court decisions have already consolidated the prohibition of the so-called indirect expropriation, since very seldom the state measure reaches unequivocally the core of the property. V. STF, DJU 22 Sept 1995, RE 134297/SP, Rel. Min. Celso de Mello; STJ, DJU 14 abr 1991, REsp 5989/PR, Rel. Min. Garcia Vieira; STJ, DJU 3 Nov 1992, REsp 8680/PR, Rel. Min. Milton Luiz Pereira; STJ, DJU 8 Aug 1994, REsp 37950/SP, Rel. Min. José de Jesus Filho; STJ, DJU 5 Sept 1994, REsp 47865/SP, Rel. Min. Demócrito Reinaldo; STJ, DJU 6 Mar 1995, REsp 45330/SP, Rel. Min. Antônio de Pádua Ribeiro; and STJ, DJU 24 Aug 1998, REsp 70412/SP, Rel. Min. Ari Pargendler.

35 See on taxes with confiscatory effects, TORRES, Ricardo Lobo Torres, A idéia de liberdade no Estado patrimonial e no Estado fiscal. Rio de Janeiro: Renovar, 1991.

36 "Well, the nationalization of (...), which took the form of confiscation, without just indemnification, openly and violently violates the fundamental principles of Brazilian law, already quoted, present in our Constitution. Contrary, consequently, to public policy, it will not be effective in Brazil, Article 17 of the New Introductory Law" (emphasis in the original). And the author continued: "It is interesting to point out that the affidavit refers to cases of nationalization without indemnification practiced by the former Soviet Union, which were not recognized with regard to assets located abroad due to the practice of confiscation. As a matter of fact, this is exactly what the decision under analysis aims to achieve". VALLADÃO, Haroldo. Ineficácia, no Brasil, da nacionalização por Estado estrangeiro, de pessoa jurídica de direito privado, sem indenização aos respectivos sócios, Boletim da Sociedade Brasileira de 
opinion, so that, in Brazil, the effects of expropriation, without the payment of any indemnification, were not granted recognition.

In this particular aspect, one should take into account the fundamental principle of equality before the law, guaranteed by the Constitution (CF, Article 5, caput). This point is of no complexity whatsoever. Whenever expropriating a private property, the State incorporates a benefit that will be enjoyed by the whole population, resulting from the sacrifice of a single individual ${ }^{37}$. Hence, the principle of equality before the law does not admit that a single person be obliged to take the burden of an advantage that will be enjoyed by society as a whole; in such cases, as everyone will be benefited, likewise the cost should also be borne by all, and the duty to indemnify is imposed ${ }^{38}$.

If it were not so, there would be unjust enrichment of the State to the detriment of the individual. The prohibition of unjust enrichment is a general principle applicable both in the private and the public law arena ${ }^{39}$, considered by court decisions as implicit in the

Direito Internacional 9/10:151.

37 "In truth, the juridical principle raised by the topic is the equal distribution of public burdens. Anyone who renders a service to the population, under the circumstances to be discussed further on, will be paid for it, even without a formal juridical relationship, because, due to an action or omission of the State, he was unfairly disadvantaged as compared to his fellow citizens, with regard to the division of general public burdens”. FIGUEIREDO, Lúcia Valle e Sérgio Ferraz. Dispensa e Inexigibilidade de Licitação. São Paulo: Malheiros, 1994, p. 128.

38 "The most important issue is the principle of fair division of the burdens or advantages, comprised in the principle of equality before the law (...). The expropriation, when it is not a punishment, implicates a special burden on the property of a certain individual for the fulfillment of a public interest. Everyone will benefit, but only one particular individual will be prejudiced. This is not fair and represents a violation of the rule of equality before the law. Fair indemnification entails sharing the burden with the population as a whole and compensating as much as possible the owner of the property, who receives a compensation equivalent in value to the property taken". ASCENSÃO, José de Oliveira , A violação da garantia constitucional da propriedade privada por disposição retroativa, Revista da Consultoria Geral do Estado do Rio Grande do Sul v.18, p.87.

39 "We were lacking, as a consequence, the construction of the unjust enrichment as an institution with autonomy and its own rules. In the development of these rules, it will be necessary to take into account the specific requirements, based on the German legal commentators, as follows: 1) reduction in the assets of the harmed individual, either with the transfer to someone else's assets, of some property which belonged to him, or which the obstruction that such property - which acquisition was already certain - becomes part of his assets; 2) the enrichment of the benefited, without the existence of a juridical cause to justify the acquisition or retention; and 3 ) the connection between both, that is the enrichment of one party must derive from the reduction of the assets of the other, in such a way that the one to had his assets reduced can argue towards the other a juridical cause non-existent or that has disappeared, or to put it more simply, the enrichment of one individual and the reduction of the assets of the other originate from the same circumstance." PEREIRA, Caio Mário da Silva Pereira, Instituições de direito civil, vol. II. Rio de Janeiro: Forense, 2002, p. 276: and "Unjust enrichment is the increase of 
Constitution $^{40}$. No one is allowed to increase his assets in prejudice of someone else's without legitimate cause. In the case of relationships between the Public Administration and private agents, this prohibition becomes even stricter ${ }^{41}$ due to the imbalance of power that exists between the parties.

Before examining procedural public policy, a last note should be made on this point. It is not incumbent upon the Judiciary or upon Brazilian law to discuss the validity of acts practiced abroad by the foreign government within the confines of its territory ${ }^{42}$. Only the foreign Judiciary has jurisdiction to adjudicate such cases ${ }^{43}$. Neither would it be admissible for the harmed party to requested indemnification in Brazil because of the expropriation that took place abroad. The foreign Judiciary would be solely competent for that matter as well. The point here at stake are the effects of the foreign decision in Brazil.

\section{PROCEDURAL PUBLIC POLICY}

\section{As mentioned earlier, procedural grounds are also part of the}

someone's assets in detriment to someone else's assets, without a reasonable juridical cause to justify it. It is widely accepted that its prohibition is a general principle of law. Given that unjust enrichment is a general principle of law - and not only a principle located in one of its branches: public or private - it certainly also applies to administrative law" (emphasis in the original). MELLO, Celso Antônio Baneira de. O princípio do enriquecimento sem causa em direito administrativo, Revista de Direito Administrativo, v 210, 1992, p. 28.

40 On several occasions, the Federal Supreme Court has deemed the principle which prohibits unjust enrichment as an implicit constitutional principle, also to justify the filing of extraordinary appeals. This can be observed in the following decisions: DJU 8 Mar 2002, RE 222368, Rel. Min. Celso de Mello; Informativo STF 181, RE 231655, Rel. Min. Moreira Alves; Informativo STF 286, RE 282120, Rel. Min. Maurício Corrêa; and Informativo STF 31, RE 141298, Rel. Min. Marco Aurélio.

41 MELlO, Celso Antônio Baneira de. O princípio do enriquecimento sem causa em direito administrativo, Revista de Direito Administrativo, v 210, 1992, p. 24 et ss.

42 Jacob Dolinger refers to this understanding as the "theory that considers that the acts originated form the ius imperii of the other country cannot be examined by the Judiciary of another country. DOLINGER, Jacob. A divida externa brasileira: solução pela via arbitral. Rio de Janeiro: Renovar, 1988, p. 99.

43 See the classic opinion of the President of the US Supreme Court in the case Underhill v. Hernandez (168 U.S. 250 - 1897): "Every sovereign state is bound to respect the independence of every other sovereign state, and the courts of one country will not sit in judgment on the acts of the government of another, done within its own territory. Redress of grievances by reason of such acts must be obtained through the means open to be availed of by sovereign powers as between themselves. Nor can the principle be confined to lawful or recognized governments, or to cases where redress can manifestly be had through public channels. The immunity of individuals from suits brought in foreign tribunals for acts done within their own states, in the exercise of governmental authority, whether as civil officers or as military commanders, must necessarily extend to the agents of governments ruling by paramount force as matter of fact". 
concept of public policy and can prevent the recognition of a foreign decision. Although the concept of public policy was developed at first in the context of substantive rights, the rights inherent to the procedural due process clause, such as the right to confrontation, to present one's claim or defense and to the respect of res judicata, e.g., of essentially procedural nature, are also part of the fundamental rights and guarantees, mentioned and protected by the Constitution. It is not possible to deny its importance in relation to the concept of second grade public policy the one able to prevent the recognition of foreign decisions.

Indeed, the 1988 Brazilian Constitution has contemplated procedural due process within the set of individual rights and guarantees, setting forth that "no one shall be deprived of freedom or of his assets without the due process of law" (Article 5, LIV). In addition to this, the constitutional legislator has expressly mentioned some of the contents of the clause, such as the impossibility of setting aside judicial control $^{44}$, confrontation and the right to present one's defense ${ }^{45}$, and the requirement that all judicial decisions must have grounds ${ }^{46}$. These principles, although individually contemplated in the constitutional text, derive from the right to procedural due process ${ }^{47}$.

It is certain that some aspects of the procedural due process of law clause - particularly regarding the competence of the judicial authority and validity of service - are expressly mentioned in the applicable legislation (Articles 15 and 17 of the LICC, already mentioned, and Articles 5 and 6 of Resolution No. 9/2005 of STJ) as formal requirements essential for recognition to be granted. These requirements are part of a more comprehensive guarantee, fundamental to the Brazilian legal system and which is associated to a procedural aspect of public policy, referred to in Article 17 of the LINDB ${ }^{48}$. The

$44 \mathrm{CF}$, Article 5, XXXV: "the law shall not exclude any injury or threat to a right from the appreciation of the Judiciary".

$45 \mathrm{CF}$, Article 5, LV: "litigants, in judicial or administrative processes, as well defendants in general are ensured of the adversarial system and of full defense with the means and resources inherent to it".

46 CF, Article 93, IX: "all judgments of the Judiciary shall be public, and all decisions shall be motivated, under penalty of nullity, and the law may, if the public interest so requires, limit attendance in given acts to the interested parties and their lawyers, or only to the latter".

47 See, regarding the treatment of the due process of law clause by the 1988 Brazilian Constitution, BARROSO, Luís Roberto, Tutela e efetividade do direito constitucional à liberdade. In: Anais da XVII Conferência Nacional dos Advogados, 1999, and also Temas de direito constitucional, volume I. Rio de Janeiro: Renovar, 2000.

$48 \mathrm{It}$ is worth pointing out that there are some procedural requirements expressly mentioned in the legislation which prevent recognition, such as the international incompetence of the foreign authority and the service of the defendant domiciled in Brazil through other means than through rogatory (letters a and b of Article 15 of the LICC, cited above), in which cases there is no need to resort to the concept of procedural public policy. 
Federal Supreme Court has not failed to perceive this point, as can be observed from the analysis of the decision below:

"1. With regard to recognition, the indispensability of the judicial proceeding of rogatory letters in the service of persons resident in Brazil, who are defendants in suits filed abroad, has acquired greater legitimacy after the enactment of the 1988 Brazilian Constitution, as it became a guarantee of effectiveness of the due process of law, of confrontation and the right to present one's defense, principles expressly consecrated in items LIV and $L V$ of Article 5 of the Charter. 2. Precedents of this Court in relation to the subject: SEC 6.729, Rel. Min. Maurício Corrêa, DJ 07.06.2002, SEC 6.304, Rel. Min. Sepúlveda Pertence, SE 4.605-AgR, Rel. Min. Carlos Velloso, DJ 13.12.96, SE 4.248, Rel. Min. Carlos Velloso, DJ 20.11.91, SE 3.495, Rel. Min. Octavio Gallotti, DJ 25.10.85 and SE 2.582AgR, Rel. Min. Xavier de Albuquerque, DJ 28.08.81. 3. Request of recognition of foreign judgment denied." 49

Precisely along the same lines, the Federal Supreme Court has already denied recognition to foreign decisions because some rights inherent to the procedural due process clause had been disregarded in the proceedings abroad, even if these rights were not the ones expressly mentioned in Article 15 of the LNDB. The following decisions are representative of this point:

“(...) 3. Essential for the recognition of a foreign decision granting exequatur to an arbitral award is that in the proceedings abroad the right to confrontation was granted to the parties. Precedents of the STF. (...) "'50

"Foreign decision. Administrative decision. Limitation of jurisdiction. A hybrid administrative decision and rendered outside the Judiciary may not be recognized, nor the judicial decision that ratifies or incorporates it, as it would greatly violate the principles of civil jurisdiction and the

49 STF, DJU 7 May 2004, SEC 7394/Portugal, Rel. Min. Ellen Gracie.

50 STF, DJU 26 May 1995, SEC 3897/IN, Rel. Min. Néri da Silveira. 
right to confrontation. ${ }^{, 51}$

As a matter of law, normally the legislation of States does not expressly refer to procedural public policy - and neither does Brazilian legislation. Nevertheless, these grounds have been employed by the competent authorities of several states, for the same reasons that justify the application of substantive public policy, to prevent recognition of foreign decisions in violation of basic guarantees of procedural due process. It is worth mentioning some examples.

In Switzerland, the concept of second grade public policy has been built by a series of court decisions ${ }^{52}$. On December 18, 1987 the concept of procedural public policy, developed by court decisions, was incorporated in the Loi fédérale du 18 décembre 1987 sur le droit international privé (legislation on private international law). After the enactment of this law, the subject was again examined by the Swiss Federal Tribunal, which has continued to affirm the need to assure the parties of some minimum procedural rights for the decision to be recognized in Switzerland ${ }^{53}$.

In France, the requirements for the recognition of foreign judgments (including procedural due process) were listed by the Cour de Cassation $^{54}$. The Court set forth five conditions without which recognition

51 STF, DJU 2 Jan 1974, SE 2161, Rel. Min. Bilac Pinto.

52 Among many decisions of the Swiss Federal Tribunal (the highest court of the country) two are worth mentioning: (i) decision of the First Chamber of Public Law, of May 20, 1981, in which it was affirmed that public policy encompasses not only aspects of merits, but also elements related to the proceeding in which the foreign decisions, object of the request for recognition in Switzerland, were rendered (Swiss Federal Tribunal, I.S. Kano Trading Limited gegen The Sanko Steamship Company Limited und Kassationsgericht des Kantons Zürich, I. Öffentlichrechtlichen Abteilung, 20. Mai 1981, BGE 107 IA 198) and (ii) decision of the same tribunal, dated March 13, 1985, which did not recognize the foreign decision since both its merits and the proceeding abroad violated the Swiss public policy (Swiss Federal Tribunal, Beyeler Machines S.A. contre Alipoor et Vaud, Ire Cour de droit public, 13 March 1985, BGE 111 IA 12).

53 Along these lines, among many others, the following decisions of the Swiss Federal Tribunal: Société R. contre P. et Cour de justice du canton de Genève, Ire Cour civile, 19 décembre 1990, BGE 116 II 625; and C. contre C.-E., IIe Cour civile, 4 juillet 2000, BGE 126 III327.

54 The first decision about this point was rendered in the famous case Munzer. This is the precedent in France in relation to recognition of foreign decisions, in which the requirements for recognition were first established. French Cour de Cassation, Munzer, $1 \mathrm{er}$ ch. civ., 7 janvier 1964, Revue Critique de Droit International Privé, p. 344, with comments from Batiffol. See an extract of the decision, in the original: “(...) pour accorder l'exequatur, le juge français doit $s$ 'assurer que cinq conditions se trouvent remplies, à savoir la compétence du tribunal étranger qui a rendu la décision, la régularité de la procédure suivie devant cette juridiction, l'application de la loi compétente d'apres les règles françaises de conflit, la conformité à l'ordre public international et l'absence de toute fraude à la loi." "to grant the exequatur, the French judge 
is not possible: (i) competence of the foreign court that rendered the decision; (ii) regularity of the proceeding abroad; (iii) applicability of the competent legislation in accordance with the French connecting rules; (iv) conformity with international public policy; and (v) absence of fraud to the law (fraude à la loi). Soon afterwards ${ }^{55}$, this same Court delineated the concept of "regularity of the proceedings" (regularité de la procédure), emphasizing, together with legal commentators ${ }^{56}$, that it should be examined in the light of French international public policy and in respect of the right to present one's defense.

Also with regard to the legislation in force within the European Union, the regularity of the proceeding abroad is comprehended within the concept of public policy. Communitarian law does not expressly mention procedural public policy ${ }^{57}$, as it only goes so far as to say that the foreign decision will not be recognized if the defendant is not served or if service is defective ${ }^{58}$. Nevertheless, the Tribunal of Justice of the

should make sure that five conditions are fulfilled, namely, the competence of the foreign court which rendered the decision, regularity of the proceedings in that foreign jurisdiction, applicability of the competent legislation in accordance with French connecting rules, agreement with international public policy and absence of all fraud." More recently, in the case these conditions have been reduced to three: "Mais attendu que, pour accorder l'exequatur hors de toute convention internationale, le juge français doit s'assurer que trois conditions sont remplies, à savoir la compétence indirecte du juge étranger, fondée sur le rattachement du litige au juge saisi, la conformité à l'ordre public international de fond et de procédure et l'absence de fraude à la loi ; que le juge de l'exequatur n'a donc pas à vérifier que la loi appliquée par le juge étranger est celle désignée par la règle de conflit de lois française ; que, par ce motif de pur droit, substitué à ceux que critique le moyen, l'arrêt attaqué se trouve légalement justifié”. Cour de Cassation, 1er ch. civ., 20 février 2007, ( pourvoi ${ }^{\circ}$ 05-14082), available at http://www.legifrance.gouv.fr/affichJuriJudi.do?oldAction=rechJuriJudi\&idTexte=JURITEXT000017636147\&fastReqId $=471729688 \&$ fastPos $=1$.

55 French Cour de Cassation, Bachir, 1er ch. civ., 4 octobre 1967, Revue Critique de Droit International Privé, p. 98, with notes by Lagarde. See, in the original: “(...) si le juge de l'exequatur doit vérifier si le déroulement du procès devant la juridiction étrangère a été régulier, cette condition de régularité doit s'sapprécier uniquement par rapport à l'ordre public international français et au respect des droits de défense. " “(...) as the judge of the exequatur should verify whether the development of the proceedings abroad was regular, this condition should be analyzed solely with regard French international public policy and in relation to the right to present one's defense. "

56 In the same sense, see among French legal commentators, AUDIT, Bernard. Droit international privé, p. 402.

57 Neither the Brussels Convention, nor Regulation (EU) No. 44/2001 deals with this point. The Regulation was published in the Jornal Oficial das Comunidades Européias, série L, no 12 of January 16, 2000, p. 1-23, and is in force in all member-states of the European Union, with the exception of Denmark.

58 The subject is regulated in $\S 2$ of Article 34 of Council Regulation (EU) No. 44/200. The provision lists the grounds on which to deny recognition of a decision rendered by a memberstate. See Hélène Gaudemet-Tallon, Competénce et exécution de jugements en Europe 402-405, 
European Community - TJCE - has consolidated the understanding that within the general public policy provision ${ }^{59}$ other violations of a procedural nature are included ${ }^{60}$, in addition to those related to service, such as, for instance, the right to present one's defense and confrontation $^{61}$.

In sum: just like in other States, also in Brazil the foreign decision shall not be recognized if some basic elements of procedural due process were not observed abroad, as this guarantee is part of Brazilian procedural public policy, which is deemed to be a fundamental principle.

\section{CONCLUSIONS}

\section{It is possible to summarize the main ideas developed throughout this study in the following objective propositions:}

p. 323-8.

$59 \S 1$ of the same Article 34 sets forth that a decision will not be recognized if the recognition is contrary to the public policy of the forum.

60 Stressing the connection between the fundamental procedural rights and the public policy clause, WATT, Horatia Muir, Revue critique de droit international privé, 2000, p. 492, emphasizes: "En effet, alors même qu'il aurait pu sembler légitime de rattacher le grief invoqué à l'hypothèse envisagée par l'article 27-2o, en tant qu'étaient en cause les droits procéduraux du défendeur défaillant, la Cour n'hésite pas à confier à l'ordre public de l'article 27-1o la fonction de veiller au respect des droits fondamentaux de la procédure. Faisant primer à nouveau la protection due à ces derniers sur le sens apparent de la lettre de la Convention de Bruxelles, elle refuse de réduire cette protection à la sauvegarde très réduite qu'offre l'alinéa 2 du même texte aux droits de la défense". "Indeed, even if seemed reasonable to limit the defense of the defendant in default to the circumstances mentioned in Article 27.2, the Court has not hesitated to employ the concept of public policy mentioned in Article 27.1 to assure protection to the procedural due process of law clause. The protection due to these rights prevail over the apparent meaning of the Brussels Convention and the Court refuses to reduce this protection to the few requirements mentioned in number 2 of the same text."

61 The decision was rendered in the case Krombach, which dealt with a request addressed to the Court of Justice of the European Communities, as per the covenant of June 3, 1971 relating to the interpretation by the Court of the convention of September 27, 1968 on jurisdiction and execution of decision in civil and commercial matters. It is interesting to quote the following extract of the decision: "44. From this evolution in court decisions it is possible to conclude that the public policy clause must be resorted to in the exceptional circumstances in which the guarantees established in the State of origin of the decision and in the convention itself are not enough to protect the defendant of a clear violation in his right to present his defense in front of the foreign tribunal, such as guaranteed by the ECHR". (Court of Justice of the European Communities, Krombach, Case C-7/98, j. 28.03.2000, Colectânea da Jurisprudência do Tribunal de Justiça e do Tribunal de Primeira Instância, 2000, p. I-1935, also published in Journal du Droit International, p. 690, 2001, notes by Huet; Revue Critique de Droit International Privé, 2000, p. 481, notes by Muir-Watt; Revue Trimestrielle de Droit Civil, 2000, p. 944 , notes by Raynard). 
A) A foreign decision can be recognized by the STJ and produce effects in Brazil once some formal requirements are observed (LINDB, Article 15) and as long as it does not violate national sovereignty, good morals and Brazilian public policy (LINDB, Article 17). For the purposes of the present study, the relevant element to be considered is public policy.

B) The public policy that prevents recognition of foreign decisions, known as second grade public policy, corresponds to a selection of the most important mandatory rules of Brazilian law. This selection comprises the fundamental elements of the legal system, and their importance prevents the production of effects, in Brazil, of a foreign decision that disrespects them.

C) The meaning of the public policy clause should resort to the category of fundamental principles, which is referred to in Article 102, $\S 1$ of the Constitution, in which are included the principles mentioned in Articles 1 to 4 and the fundamental rights, listed under Article 5 of the constitutional text. The concept of public policy presents a substantive dimension, related to the content of the decision (merits) and another one, of a procedural nature, related to the regularity of the proceedings which originated the foreign decision, taking into account the minimum guarantees of the procedural due process clause.

\section{REFERENCES}

ASCENSÃO, José de Oliveira. A violação da garantia constitucional da propriedade privada por disposição retroativa, Revista da Consultoria Geral do Estado do Rio Grande do Sul, Porto Alegre, n. 18, p. 73, 1973. AUDIT, Bernard. Droit international privé. Paris: Economica, 2013. ÁVILA, Humberto. Sistema Constitucional Tributário. São Paulo: Saraiva, 2006.

BARROSO, Luis Roberto. O controle de constitucionalidade no direito brasileiro: exposição sistemática da doutrina e análise crítica da jurisprudência. São Paulo: Saraiva, 2012.

BARROSO, Luís Roberto. Tutela e efetividade do direito constitucional à liberdade, Anais da XVII Conferência Nacional dos Advogados, Brasília: EDITORA OAB, 2000.

BORGES, Alice Gonzalez. Valores a serem considerados no controle jurisdicional da Administração Pública: Segurança Jurídica - Boafé - Conceitos indeterminados - Interesse público. Revista Interesse Público, Salvador: Fórum, v.15, p. 83-96, jul./set. 2002.

COSTA, Judith Martins. Boa-fé no Direito Privado. São Paulo: RT, 
2000.

DELGADO, José Augusto. O princípio da moralidade administrativa e a Constituição Federal de 1988, Revista dos Tribunais, São Paulo: Revista dos Tribunais, Ano 81, nº 680, p. 34, Jun/1992.

DI PIETRO, Maria Sylvia Zanella. Direito Administrativo. São Paulo: Atlas, 2012.

DOLINGER, Jacob. Ordem pública mundial; ordem pública verdadeiramente internacional no direito internacional privado, Revista de Informação Legislativa do Senado Federal, Brasília, Ano 23, nº 90, p. 211, abr./jun. 1986.

DOLINGER, Jacob. Direito Internacional Privado - parte geral. Rio de Janeiro: Renovar, 2008.

DOLINGER, Jacob. A divida externa brasileira: solução pela via arbitral. Rio de Janeiro: Nova Fronteira, 1988.

FIGUEIREDO, Lúcia Valle e Sérgio Ferraz. Dispensa e Inexigibilidade de Licitação. São Paulo: Malheiros, 1994.

FIGUEIREDO, Marcelo. Controle da moralidade na Constituição, SP: Malheiros, 1999.

GAUDEMET-TALLON Hélène, Compétence et exécution des jugements en Europe, Paris: LGDJ, 2002.

MELLO, Celso Antonio Bandeira. Contrato administrativo: Fundamentos da preservação do equilíbrio econômico financeiro, Revista de Direito Administrativo, n 211, p. 22, Jan/1998.

NEGREIROS, Teresa. Fundamentos para uma interpretação constitucional do princípio da boa-fé. Rio de Janeiro: Renovar, 1998.

PEREIRA, Caio Mário da Silva. Instituições de Direito Civil. vol. II, Rio de Janeiro: Forense, 2009.

PEREZ, Jesus Gonzalez. El principio general de la buena fe en el Derecho Administrativo. Madrid: Civitas S/A, 1989.

TEPEDINO, Gustavo. A nova propriedade (O seu conteúdo mínimo, entre o Código Civil, a legislação ordinária e a Constituição), Revista Forense, Rio de Janeiro: Forense, V. 85, nº 306, p. 73, abr./jun. 1989. TORRES, Ricardo Lobo. Os direitos humanos e a tributação: imunidades e isonomia. Rio de Janeiro: Renovar, 1995.

TORRES, Ricardo Lobo. A Ideia de Liberdade no Estado Patrimonial e no Estado Fiscal. Rio de Janeiro, Renovar, 1991

VALLADÃO, Haroldo. Ineficácia, no Brasil, da nacionalização por Estado estrangeiro, de pessoa jurídica de direito privado, sem indenização aos respectivos sócios, Boletim da Sociedade Brasileira de Direito Internacional 9/10:151

Colectânea da Jurisprudência do Tribunal de Justiça e do Tribunal de Primeira Instância, 2000. 